Student ID number: 300287382

Assignment 2: Research report

INFO 580: Research Project

5 June 2015

School of Information Management

Faculty of Commerce

Victoria University of Wellington 


\title{
Whāia te mātauranga - How are research libraries in Aotearoa New Zealand applying Ngā Ūpoko Tukutuku / the Māori Subject Headings and offering them to users?
}

\author{
by
}

\section{Melissa Bryant}

Submitted to the School of Information Management,

Victoria University of Wellington

in partial fulfilment of the requirements for the degree of

Master of Information Studies

June 2015 
INFO 580 research project report

\title{
Whāia te mātauranga
}

\author{
How are New Zealand research libraries applying \\ Ngā Ūpoko Tukutuku / the Māori Subject Headings \\ and offering them to users?
}

\begin{abstract}
Melissa Bryant
Master of Information Studies, School of Information Management Victoria University of Wellington
\end{abstract}

5 June 2015

Whäia te mätauranga hei oranga mō tātou.

Seek after learning for the wellbeing of all. 


\section{Acknowledgements}

\section{Ehara taku toa $i$ te toa takitahi, engari he toa takitini.}

My strength is not the strength of one alone; it is the strength of many.

Ko te mea tuatahi, ka nui ngā mihi ki a koutou, ngā kaiwhakauru, ngā kaiārahi, ngā tāngata e tautoko mai ki te rangahau nei. I must begin by thanking all those who have guided, supported and contributed to this small research project.

Ki ngā kaihautū me ngā kaimahi o Ngā Ūpoko Tukutuku, o mua, o tēnei wā tonu - tēnā koutou e ngā rangatira. My grateful thanks go to all those within Te Whakakaokao/the Māori Subject Headings Working Group, the Māori Subject Headings Governance Group, and the Te Ūpoko o te Ika rohe/region of Te Rōpū Whakahau, who have so graciously offered their encouragement and advice, and to those whom I never met, who were striving to improve information equity through the Māori Subject Headings project for years before I ever worked in a library.

Ki ngā kaitiaki kōrero nāna tēnei mahi rangahau i tautoko, tēnā koutou. Many thanks to the librarians who shared their precious time, expertise and stories with me during this research.

Ki ngā tāngata whenua o ngā motu, o Te Wai Pounamu me Te Ika a Māui - tēnā koutou. I acknowledge the peoples of the South Island, where I was raised, and the North, where I worked on this research. Ki ngā tūpuna o tōku whānau kua tae mai i tawhiti, tēnā tātou. I acknowledge my own ancestors, who came to these islands from some other little islands and one very big one on the other side of the world around 150 years ago, and have been learning to live here ever since.

Ki ōku kaiako, ki ōku pūkenga, tēnā koutou. I acknowledge the lecturers and administrators of the School of Information Management of Victoria University who have helped to make this project a reality, as well as our indefatigable senior tutor Kathryn. Special thanks for the enthusiasm and positivity of my supervisor Dr. Sydney Shep, who can always see a way forward.

Otirā, i ngā mea katoa, ki tōku whaiāipō, arā ko tōku poutokomanawa. And lastly I thank my brilliant, hilarious, and very patient Amos, who aids and exacerbates my addiction to learning and supports me in all things. Ok, now we can spend some time properly planning the wedding. 


\section{Table of Contents}

Abstract 1

Research problem $\quad 2$

Literature review $\quad 5$

$\begin{array}{ll}\text { Theoretical framework } & 7\end{array}$

Research question and implications for research design 10

$\begin{array}{ll}\text { Study objectives } & 12\end{array}$

Definitions of key terms $\quad 12$

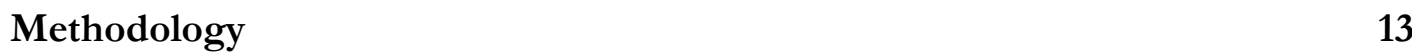

- Population and sample 13

- Ethical considerations 14

- Limitations and delimitations 15

- Data collection 16

- Data analysis 17

$\begin{array}{ll}\text { Results and discussion } & 17\end{array}$

Conclusions $\quad 30$

References

Appendix 1. Research question and sub-questions 43

Appendix 2. The "long list" of research questions 45

Appendix 3. Participant information sheet and consent form 49

Appendix 4. Interview schedule 53 


\section{Abstract}

Ngā Ūpoko Tukutuku/the Māori Subject Headings (MSH) were released in 2006, with the aim of "provid[ing] a structured path to subjects that Māori customers can... use to find material in libraries...using terms familiar to Māori and arranged in a hierarchy that reflects the Māori view of the world". The project is a world leader and internationally well-regarded, but very little literature has been published evaluating the uptake and use of the MSH.

I talked with staff in wānanga, university, public, and special libraries, to explore how research libraries are applying the MSH and offering the MSH to their users, when adding metadata, providing reference and research services, or supporting library users to search independently.

Libraries employed diverse approaches tailored to their specific users, but participants consistently emphasised the importance of the MSH, advocated for further development of the thesaurus, and hoped for more training and information sharing between libraries.

Results are discussed in terms of four questions - What is working well? What could work better? What are the benefits of this work? What further questions do we need to answer?

Suggestions for further research include broader assessment of the actual and potential uptake of the MSH in libraries and other memory institutions, discussion with library users, and consideration of the future development of the MSH.

\section{Keywords}

\section{Mātauranga}

Whare pukapuka

Iwi taketake

$\underline{\text { Libraries and indigenous peoples }}$

Maori (New Zealand people) and libraries

Biculturalism--New Zealand 


\section{Research problem}

Ngā Ūpoko Tukutuku/the Māori Subject Headings (MSH) were released in 2006, through collaboration between LIANZA (the Library and Information Association of New Zealand Aotearoa), Te Rōpū Whakahau ("the leading national body that represents Māori engaged in culture, knowledge, information, communication and systems technology in Aotearoa New Zealand" - Te Rōpū Whakahau, 2015a), and the National Library of New Zealand; and are periodically updated (Te Whakakaokao, 2013).

The aim of the MSH is to "provide a structured path to subjects that Māori customers can... use to find material in libraries" by providing "subject access...using terms familiar to Māori and arranged in a hierarchy that reflects the Māori view of the world" (Paranihi, 2013). This is in contrast to other subject heading systems such as the Library of Congress Subject Headings (LCSH), which may limit access to materials by labelling them with misleading, offensive, unfamiliar and/or insufficiently specific terms (Amey, 2012; Coleman \& Marshall, 2014; East et al., 2007; Irwin \& Katene, 1989; Simpson et al., 2005; Tobin, n.d.; Webster \& Doyle, 2008).

Examples of such obstructively inaccurate description are well documented. During advance planning of the MSH, a hui participant in Simpson et al.'s 2005 study pointed out that "all of our stories get called 'Myths and Legends', but ... a lot of that is about whakapapa ... they're not myths at all" (p. 50). Whakapapa, sometimes translated into English as "genealogies", are extended conceptual networks which link together people and things within the physical and spiritual world in mnemonic systems of attributes and causal connections which are of real practical significance in guiding daily behaviour (Barlow, 1991, p. 173; Ka'ai et al., 2004, p.15; Moorfield, 2003; Simpson et al., 2005, pp. 28-29). Another participant recalled that the book "The Rhythm of Life and Poi" by Ngāmoni Huata had been assigned an LCSH subject heading with the suffix "antiquities" (p. 53), a surprising choice to describe an art form and a method of memorising and communicating which is very much alive today. Amey (2012) cited "mana whenua" as another concept with no good match in the LCSH -

... the LC heading for 'Land tenure' has quite a separate meaning from 'Mana whenua' which has the English scope note [in the MSH] "Customary law relating to the iwi/tribe's connection, ownership rights and role of stewardship to a particular area of land." 
Mana whenua differs from Western "land tenure" in many ways - for example, neighbouring groups of people may be linked through mana whenua by overlapping interests in and responsibilities over various resources in an area, rather than being divided by exclusive rights to the use of separate pieces of land (Ka'ai et al., 2004, pp. 54-56). As another participant in Simpson's planning hui tactfully pointed out, concepts do not always translate simply and successfully across cultures - "that other language is not necessarily the same thing" (p. 54).

The MSH were created to address this problem, as one answer to the question so aptly worded by Tikao (Tikao \& Frean, 2013): "What can we do to ensure Māori can open our doors with their own key?". The story is often said to begin in 1989, when Irwin \& Katene noted in their classic paper (1989, p. 18) that under existing classification systems, "to find knowledge in a library you [had] to think Anglo-American ...”. A thesaurus named He Puna Kupu Māori, or "Kupu”, was released in 1994 after four years of preparation, and was primarily used for indexing within the National Library. Certain other libraries also developed their own in-house vocabularies to enhance subject access. After Szekely \& NZLIA (1997) confirmed the need for broader nationwide use of Māori subject headings, Te Rōpū Whakahau and LIANZA began to scope and plan a new thesaurus. The National Library added its strength to the project in 2003, and Simpson et al.'s 2005 report was instrumental in framing the actual construction of the resource. Then at last, the newborn Ngā Ūpoko Tukutuku / Māori Subject Headings thesaurus was presented in a "soft launch" in 2005, with an official launch in 2006 (De Barry, 1998; East et al., 2007; Lilley, 2013b; MacDonald \& NZLIA, 1993; Murray \& Barnett, 2007; Ta'ala, 2008; Taitoko, 2003; Te Rōpū Whakahau, 2015b; Te Whakakaokao, 2013; Todd, 1998).

The MSH are recognised as increasing the mana of libraries as well as library users (Paranihi, 2011b; Simpson et al., 2005), and participation in the project has provided opportunities for the National Library to take steps towards fulfilling its legislative mandate to support mātauranga Māori/indigenous knowledge systems (Macnaught, 2012). As the Waitangi Tribunal pointed out in its 2011 report "Ko Aotearoa Tēnei”, all publicly owned agencies (including information organisations and memory institutions) have a responsibility to uphold the use of te reo Māori / the Māori language in their public-facing systems.

Fundamentally, there is a need for a mindset shift away from the pervasive assumption that the Crown is Pākehā, English-speaking, and distinct from Māori rather than representative of them. ... Māori should be able to use their own language, given its official status, in as 
many of their dealings with the New Zealand State as practicable - particularly since the public face of the Crown will often be a Māori one. (Waitangi Tribunal, 2011, p. 451)

Furthermore, the importance of the MSH is likely to escalate, as both the Māori population and the number of Māori people in higher education are increasing, indicating that the numbers of information seekers whose default search language and conceptual framework are Māori will also rise (Paewai \& Reweti, 2014; Statistics New Zealand, 2013; Te Rōpū Whakahau, 2015a). One founding member of the team who constructed the MSH in 2005 is fondly remembered for sharing an enlightening story illustrating her own experience in this situation.

$[T]$ he story she told was about a visit she made to the University . . . Library when she was studying te reo Māori ... She was totally immersed in te reo and went to the library to find a resource on karakia for waka. She could not think of an appropriate English subject heading to search under, so ... went back to her lecturer who advised her to start by using the subject heading for canoes. (personal communication from a participant in this study, 26 March 2015)

A similar story is also told about a family member of the same original team member, and the lesson learned is the same - even an information seeker who is fluent and highly educated in two languages and world views can struggle to switch into one while deeply engrossed in research endeavours in another.

However, the MSH benefit not only speakers of te reo Māori, but also New Zealand English speakers who may be unfamiliar with terms used in subject heading systems developed overseas (Paewai \& Reweti, 2014). Furthermore, excellent information literacy for all information seekers must include an understanding of indigenous information issues (Bundy, 2004), so the Māori subject headings offer practical benefits for everyone.

During preparation for this study, I analysed search terms entered into one library's most popular search interfaces over two months. This analysis revealed that many searchers used terms which are included in the MSH but not in the LCSH, indicating that this library's application of MSH terms must have significantly improved the success of those searches. These terms included words which do not have direct translations into English, such as "korowai", "hongi", "tauparapara", and "Matariki", as well as words which are shared by te reo Māori and New Zealand English, such as "kawakawa" and "kūmara" (for which the LCSH uses "sweet potato", a term uncommon in New 
Zealand English). These results underscore Paewai \& Reweti's (2014) assertion that all New Zealanders stand to benefit from libraries' application of the MSH through improved discoverability and use of information resources.

Paranihi (2011a, 2011b) called for feedback on libraries' experiences with the subject headings, but a search of the Aotearoa New Zealand library literature reveals no studies examining this. Therefore, this research explored how some libraries are applying the MSH and offering the MSH to their users.

\section{Literature review}

A literature search (via nzresearch.org, New Zealand Index, the Victoria University School of Information Management's research archive, the Victoria University Library's discovery software, Google, LIANZA publications and international library literature databases) found almost no research evaluating the uptake, application or effects of the MSH. What has been written about the MSH is as follows.

First and earliest were the sequence of papers documenting the research conducted before and during the development of the MSH (Garraway \& Szekely, 1994; MacDonald \& NZLIA, 1993; Szekely \& NZLIA, 1997), culminating in Simpson et al.'s report (2005) which laid out proposed requirements for the project. Other writings during this time explained the development process of the MSH, and its relationship with its ancestor He Puna Kupu (De Barry, 1998; Garraway \& Szekely, 1994; Māori Subject Headings Working Party, 2000, 2001; Todd, 1998).

These were followed by publications aimed at explaining the MSH and raising awareness of their availability among information professionals in Aotearoa New Zealand and among the international community of indigenous librarians (Amey, 2012; East, 2008; East et al., 2007; East \& Staincliffe, 2007; Murray \& Barnett, 2007; Morehu et al., 2009; Paranihi, 2011a, 2011b; Paewai \& Reweti, 2014; Taitoko, 2003).

Praise for the MSH soon blossomed in the international literature on indigenous librarianship, where the MSH are cited as a positive example which can guide others who follow (Ghaddar \& Caidi, 2014; Maina, 2012; Nicolas, 2003; Paranihi, 2013; Webster \& Doyle, 2008). The international literature on problems with equity of subject access makes clear the importance of such initiatives, 
without which indigenous information seekers are left frustrated by obstacles such as those listed by Webster \& Doyle (2008) - "marginalisation; historicisation; omission; lack of specificity; failure to organise materials in effective ways; lack of relevance; and lack of recognition of ... sovereignty." Olson \& Schlegl (2008) proposed solutions: consider the diversity of information seekers, adapt classification to local contexts, take responsibility for this locally. The home-grown MSH, with reo a-iwi / local dialect terms and bilingual navigability, fits this model neatly.

The only writings yet published describing application of the MSH are two case studies - one from an academic library, and one for a manuscript collection within the National Library (Ta'ala, 2008; Tikao \& Frean, 2013). Ta'ala's (2008) “small and informal review" of the experiences of University of Auckland library staff recorded the challenges faced by cataloguers with limited confidence in te reo, and called for further research. Tikao \& Frean (2013) told how they used the MSH, among other tools, to describe a collection of letters taken from two kainga during the Taranaki Land Wars, and proposed measures of improved access including "the number of new conversations we are having" and "evidence of work... using and reusing the collections."

The published discourse around the MSH now exists within the context of the literature within Aotearoa New Zealand on biculturalism within libraries, including publications from Grace (1994), Garraway \& Szekely (1994), Hayes (2013), Irwin \& Katene (1989), Johnston (2007); Lilley (2012, 2013a, 2013b), Lilley \& Paringatai (2014), Parekowhai \& Black (1990), Rankin \& Steer (2013), Ritchie (2013), Stevens (2004), Waitangi Tribunal (2011, pp. 451, 527-586), Wara (2001), and Warren (2006). These works situate the need for equitable and efficient access to Māori materials in libraries within an interconnected web of challenges facing librarians and their Māori users. Many of these service limitations have been repeatedly documented since at least the early 1990s. For example, Māori staff are still sometimes over-stretched, isolated and scarce; and competency in te reo Māori among the library workforce remains limited. These issues were recognised in my research questions, as shown in the appendices to this research proposal. They were also important factors in my planning, implying that I needed to take care not to over-burden my informers and respondents.

This literature also records the huge amount of effort and expertise which has gone into developing the MSH since 1990, on a restricted budget. Although progress may have at times seemed slow for those involved, the project remains a world leader and internationally well-regarded. For comparison, Webster and Doyle (2008) note that the Library of Congress has sometimes taken 
decades to address requests from indigenous librarians in North America for adjustments to its subject heading system. As mentioned in the "Research question and implications for research design" section below, I have been privileged to attend a working session of Te Whakakaokao/the Māori Subject Headings Working Group and the Māori Subject Headings Governance Group, and have observed that the weaving of new terms into the thesaurus requires enormous knowledge, insight, and careful consideration, not only from the experts who were working within the room, but from their extended networks of correspondents, whom they consulted via text messages, telephone calls and emails throughout the process. In light of the impressive achievements thus far, accomplished with a fraction of the resources which are presumably available for the development of the LCSH, it was important that my research questions, my interactions with participants and informants, and my reporting reflected appreciation of the positive achievements gained.

Finally, these papers indicated theoretical considerations for my study in relation to Kaupapa Māori methodology, as discussed in the "Theoretical framework" section of this research proposal below.

\section{Theoretical framework}

Much of the above research was conducted with reference to Kaupapa Māori methodology. As a solo Pākehā researcher initiating this research from outside the organisations concerned, I was unqualified to attempt such an approach (Bishop, 2005; Smith, 2005).

Instead, I aimed to situate this research within a transformative paradigm - a close cousin to Kaupapa Māori research with connections through the critical theory family (Cecez-kecmanovic, 2011; Mertens, 2003, 2009, 2011, 2012). This approach required that -

- The research problem and definitions arose from the community of concern. Therefore, in planning this research, I consulted Te Whakakaokao/the Māori Subject Headings Working Group, the Māori Subject Headings Governance Group, and the Te Ūpoko o te Ika regional rōpū of Te Rōpū Whakahau.

- The strengths, agency and experiences of participants, including those from marginalised communities, were recognised. I aimed to document and celebrate some of the diversity of ways in which organisations and librarians are engaging with the MSH, creatively circumventing barriers and playing to their own strengths.

- Differing ways of understanding reality were respected, as in an interpretive-constructionist paradigm; but furthermore, these multiple viewpoints were examined within the context of 
social, economic and political power relationships, and with consideration of the consequences of accepting each perspective. I recognise that in a complex world of limited resources and competing priorities, the full potential of the MSH may not yet be realised. I encouraged participants to raise any matters they wished during interviews, accepting the relevance of many inter-related issues.

- The results are reported with the aim of facilitating action and social change. I openly affirm that I believe the MSH have huge potential for improving information equity in Aotearoa New Zealand. My exploratory data analysis, as described in the "Problem statement" section of this report, indicated the power of the MSH to improve access to information for those, like me, for whom New Zealand English is their first language, as well as information seekers who are strong in te reo Māori, and even international researchers seeking information on Māoritanga or any Aotearoa New Zealand topics.

- The researcher declares her biases and reveals her background. When meeting with participants and informants, I explained that although I now live in Wellington, I was raised in the South Island, with strong connections to Christchurch, Dunedin, Motueka and Greymouth. However, my family is Pākehā and my great-great- and great-great-greatgrandparents are all from what is now Germany, Ireland and the United Kingdom. I learned early on to communicate this clearly, as perhaps in light of the kaupapa/purpose of this study, it was possible for others to assume that I was Māori, and that this misunderstanding could be difficult to undo. My motivations in asking to approach this topic for research are expressed by the following words.

- "Access to Māori information is the responsibility of both Treaty partners" (Māori Subject Headings Working Party, 2000).

- "If you have come here to help me, you are wasting your time. But if you have come because your liberation is bound up with mine, then let us work together." [The elder and academic Lilla Watson asks that these words be credited to "Aboriginal activists group, Queensland, 1970s” (Lilla: International Women’s Network, n.d.; Margaret, 2013; Watson, 2004).]

Within this framework of transformative research, I aspired to apply what principles of Kaupapa Māori research I could, in the following interconnected ways (Bishop, 2005; Hudson et al., 2010; 
MacDonald \& NZLIA, 1993; Margaret, 2013; Mead, 2003, pp. 317-318; Mertens, 2009; Pipi et al., 2004; Simpson et al., 2005; Smith, 2005; Wehipeihana et al., 2010; Wehipeihana et al., 2013) -

- Responsiveness

- The research problem and the research plan were constructed and defined alongside informants with context-specific expertise.

- I asked participants' preferences regarding such matters as whether communication is written or oral, whether interviews involved individuals or groups, and what was their preferred environment to meet.

- I offered to meet kanohi ki te kanohi / face-to-face, especially in initial interactions.

- Reciprocity

- Participants were asked what koha/gift/contribution they expected in return for their contribution.

- I offered to return research results to participants in a format preferred by them, accepting their mana to do whatever they choose with this information, even if that is nothing.

- Respect

- I aimed to act as a guest in others' spaces and organisations, not presuming to offer advice, and following their kawa/etiquette.

- I assured contributors that they retained rangatiratanga/sovereignty and mana motuhake / autonomy regarding their comments, and therefore could amend or withdraw them at any time.

- I aimed to show recognition and appreciation of positive achievements, strengths and efforts.

- I tried to observe and listen well before speaking.

- Integrity

- I honestly described what could be achieved with the resources and time available, explaining that this small research project was conducted as just one six-month parttime paper within a taught Masters, and therefore could not encompass such extensive research as a Masters by thesis.

- I considered the implications of my actions for others connected with participants for example, being tactful in reporting any information about intra-organisational controversies. 
- I aimed to communicate clearly, and where possible, privileged Māori terms, as English translations are not always fully equivalent. English language approximations of some terms are provided here to assist any international readers, or those who feel less fluent in te reo, to understand words as they are used in this context.

- Competency

- I strove to avoid overburdening contributors.

- I consulted communities of concern - in this case, libraries and professional organisations - to identify key contacts recommended by the community members.

- I checked summaries and quotations from interviews with participants, to maximise construct validity, as recommended also by researchers from outside Kaupapa Māori practice, such as Onwuegbuzie \& Teddlie (2003), Punch (2014, p. 323), and Yin (2014, p. 45).

\section{Research question and implications for research design}

This was an exploratory study in a relatively new area of research. The research question and research design unfolded together, influencing each other during the journey.

My initial research question was "How are library users using and benefiting from Ngā Ūpoko Tukutuku/the Māori Subject Headings?” However, after consultation with key stakeholders, this evolved.

I first contacted Te Whakakaokao/the Māori Subject Headings Working Group, to gain in-principle consent for me to investigate this area, and to informally discuss their priorities and preferences. They recommended that I should -

- Attend a working session of Te Whakakaokao/the Māori Subject Headings Working Group and the Māori Subject Headings Governance Group, on 22 August 2014.

- Discuss issues individually with experienced members of Te Whakakaokao, during AugustSeptember 2014.

- $\quad$ Attend a Te Rōpū Whakahau regional hui for Te Ūpoko o te Ika, on 19 September 2014. 
These discussions generated many interconnected research questions, not all of which could be addressed in this study. These questions are summarised in Appendix 2, along with notes on those which remain for further research.

After discussing the necessity of limiting the scope of this research, my key informants within Te Whakakaokao/the Māori Subject Headings Working Group identified certain high priority areas from within the initial array of potential research questions. Their first priority was to learn more about the uptake of the MSH among various types of information organisations and memory institutions, and about any factors limiting acceptance and use, and then to answer questions around implementation.

Unfortunately, the first two of these priorities could not be thoroughly addressed during this project, as I had no way to effectively contact a large number of institutions. This was because an anonymous online survey was felt to be an inappropriate model for this study, for several reasons the many inter-related research questions inviting qualitative answers, the likelihood of further questions being generated by participants, the variation between libraries, and ethical principles of research involving Māori people, which indicate a preference for kanohi ki te kanohi / face-to-face communication, as described in the "Theoretical framework" section of this research proposal above. However, I lacked the time and funds to travel extensively to meet information professionals face-to-face.

Therefore, I began with an environmental scan, gathering publicly available information to find out whatever I could about which libraries were applying the MSH, and identifying potential participants for the main phase of the research. This was followed by semi-structured interviews to investigate issues of implementation. As only a small number of libraries was included, the study utilised a qualitative approach, synthesizing the rich information contributed by participating libraries, rather than attempting to collate and analyse responses numerically across diverse institutions.

Extensive investigation of which institutions are actively engaging with the MSH, and of what factors may limit or enhance this engagement in various types of institution, must remain for future research.

The research question thus became: How are research libraries applying Ngā Ūpoko Tukutuku, the Māori Subject Headings, and offering them to users? 
- Who is adding the MSH terms, how, and with what support/guidance?

(Cataloguing/indexing/arrangement and description)

- How are librarians using the MSH terms and thesaurus when searching with users? (Reference \& research services)

- How are libraries presenting the MSH to users, and supporting/guiding their use? (Independent searching)

Further details of the components of these sub-questions are provided in Appendix 1.

\section{Study objectives}

This study explored how research libraries are applying the MSH and offering the MSH to their users, with the aim of -

- Providing one avenue for libraries to share their good ideas with each other, to facilitate the use of the MSH.

- Finding out what could work better, for the same reason.

- Documenting library staff experiences of the benefits of the MSH for staff and users, to motivate more libraries to engage with the resource.

- Documenting what areas still require further investigation by future researchers.

\section{Definitions of key terms}

\section{Research libraries.}

Libraries invited to participate in this study included libraries in Aotearoa New Zealand which are consulted often for research, including academic libraries such as wānanga or university libraries, public libraries with notable heritage collections, or special libraries such as those within government departments, Crown Research Institutes, Crown entities, or independent judicial bodies.

\section{Subject heading.}

The most specific word or phrase that describes the subject, or one of the subjects, of a work, selected from a list of preferred terms (controlled vocabulary) and assigned as an added entry in the bibliographic record to serve as an access point in the library catalog (Reitz, 2014). 


\section{Ngā Ūpoko Tukutuku/the Māori Subject Headings (MSH).}

A thesaurus of subject heading terms relevant to Māori materials and searchers, developed using

English and te reo Māori in a framework reflecting Māori understandings of knowledge, and released in 2006 by LIANZA (Library and Information Association of New Zealand Aotearoa), Te Rōpū Whakahau and the National Library of New Zealand (Te Whakakaokao, 2013). "MSH” is the abbreviation used for convenience by Te Whakakaokao members.

\section{Te reo Māori.}

Also called "te reo", or "the Māori language". The language of the indigenous people(s) of Aotearoa New Zealand, including various dialects (New Zealand Ministry for Culture and Heritage Te Manatū Taonga, 2013).

\section{Library users.}

Also called "customers", "borrowers", or "clients". Non-staff members who access a library's services and content.

\section{Thesaurus.}

A "controlled and structured vocabulary in which concepts are represented by terms, organised so that relationships between concepts are made explicit, and preferred terms are accompanied by leadin entries for synonyms or quasi-synonyms" (ISO (International Organization for Standardization), 2011).

\section{Metadata librarians.}

Metadata librarians at the organisations which participated in this study included staff who specialise in working to ensure that library resources are discoverable for library users, through metadata work such as cataloguing of published works, indexing of serials, and/or the arrangement and description of archival or special collections.

\section{Methodology}

\section{Population and sample}

It is currently unknown how many libraries in Aotearoa New Zealand are actively employing the MSH, although my initial environmental scan of publicly available information identified thirteen libraries, eight of these being in the Te Ūpoko o te Ika / greater Wellington region. It should be 
noted that the main purpose of this environmental scan was to locate potential research participants, so these results do not necessarily indicate that other regions are actually participating any less energetically in utilising the resource.

From this scan, I selected a sample of libraries including wānanga, university, public, and special libraries, to enable me to consider perspectives from various settings.

Participants were fifteen staff working within six libraries in the Te Ūpoko o te Ika a Māui/greater Wellington region which are extensively used for research and which have experience using the MSH. These individuals, each nominated by senior staff within their own libraries, all work with the MSH, whether through metadata creation (cataloguing, indexing or arrangement and description), reference and research services, Māori specialist services, or team leadership roles.

As can be seen in Appendix 2, the population of interest is much broader than this - it includes everyone working within or using information repositories in Aotearoa New Zealand. During the planning phase of this project, members of Te Whakakaokao/the Māori Subject Headings Working Group and Te Rōpū Whakahau noted the importance of consulting library users directly regarding their experience of the MSH. MacDonald \& NZLIA (1993) and Ta'ala (2008) have also identified the necessity of assessing users' views. However, due to time limitations, this was not possible during this study, and remains to be investigated in future research.

This study focused only on staff working within research libraries, because these types of libraries often hold significant collections of Māori material, were cited by several of my informants as being of particular interest, and are often accessible to a wide range of users. Also, as I have worked in some types of research library, I have some familiarity with their systems and contexts. Libraries closer to my home city were approached to participate, to allow for face-to-face communication during data collection, following the principle of responsiveness as previously mentioned in the "Theoretical framework of this study" section above.

\section{Ethical considerations}

As the MSH project was initiated especially for the benefit of Māori library users, it was important for me to follow the ethical principles of research involving Māori people previously outlined under "Theoretical framework of this study". 
Therefore, I gathered information through professional networks involving face-to-face contact with known individuals, following the principle of responsiveness. This meant that participants were not anonymous to me. Human Ethics Committee approval was granted, and I took care to maintain the confidentiality of all participants and institutions during data collection, storage and reporting. I work within one participating library, and I am a student associate member of Te Rōpū Whakahau, the Māori information professionals' association, of which some participants are also members. I was particularly careful to maintain the confidentiality of these colleagues and their organisations.

Any information gathered during informal discussions during the planning phase of this study was not included in this research report, as the stakeholders involved in these conversations had not provided formal consent for their contributions to be included in the research itself.

I gained consent to conduct research within each organisation from the appropriate managers before inviting individual staff to participate, as recommended by Punch (2014, pp. 43-47).

Interviews were conducted within participants' workplaces, so I took care to maintain the privacy of non-participants such as library users. I avoided collecting identifying information about anyone who had not given informed consent to participate in the study - for example, by ensuring that I did not accidentally record nearby conversations.

The participant information sheet and participant consent form relating to Human Ethics Committee approval are included in Appendix 3.

\section{Limitations and delimitations}

As previously mentioned -

- This study focused only on selected staff working within a small number of research libraries in the Te Ūpoko o te Ika a Māui / greater Wellington region.

- I sought only case-based explanations of each library's specific and local situation, without attempting to generalise beyond the respondents in this study, as advised by Punch (2014, pp. 22, 33).

- The scope of the research question was restricted to a tightly scoped subset of the many research questions proposed by my informants, all of which can be seen in Appendix 2.

- I aimed to situate this research within a transformative paradigm, applying what principles of Kaupapa Māori research I could, rather than attempting Kaupapa Māori methodology. 


\section{Data collection}

This study aimed to gather intensive rather than extensive information (Cecez-kecmanovic, 2011).

I collected records of kōrero/discussion, gathered through semi-structured interviews of approximately 60 minutes each. We conducted face-to-face interviews, either individually or in focus groups, according to participants' preferences. I provided interview schedules to participants in advance, to allow extra time for consideration.

I made and selectively transcribed audio recordings of the interviews, to produce a written record of timecodes along with topics or questions discussed, key information provided and pertinent quotations. As stated in the "Theoretical framework of this study" section above, I sent these selective transcriptions to participants for checking. This was a fruitful process, as several participants contributed further thoughts and stories in their replies.

The interview schedule used to guide these discussions is shown in Appendix 4.

At the beginning of each interview, we exchanged introductions, often establishing associations through connection to places or comparison of family histories. (There was one occasion on which this almost did not occur. I had arrived slightly ruffled and slightly late, after a long early morning drive, and was about to rush into discussing procedure, when my local hosts gracefully and with the warmest hospitality ensured that we all take some time to begin properly.) We then discussed the research question and objectives. I checked that participants were comfortable with note-taking, recording, data storage and confidentiality procedures, and encouraged everyone to raise any issues which seemed relevant, explaining that my aim was to generate discussion and stories, rather than to gather yes/no answers. When talking with those colleagues who had previously advised me while I was planning the research, I also confirmed that any previous informal discussions on the topic would not be included as research data, and asked that they therefore feel free to repeat information.

At the end of each interview, I confirmed that I would send a selective transcription to participants so that they could review and amend it if they wished. I reminded participants that they could withdraw from the study at any time before their contributions had been inextricably woven together with those of others during data analysis, although it would not be possible to identify and destroy only one participant's part of an audio recording of a group discussion. I also thanked participants for generously sharing their time and expertise, and sometimes we shared some 
kai/food, for whakanoatanga and whakawhanaungatanga (for relationship building and to lighten the psychological and spiritual seriousness of the meeting).

\section{Data analysis}

To maintain the confidentiality of the research participants and to shed light on commonalities and differences, my data analysis was variable-oriented rather than case-oriented, as per Onwuegbuzie \& Teddlie (2003) and Yin (2014, pp. 164-68), with information reported thematically rather than by individual institution. As only a focused selection of libraries participated in the study, I did not attempt to generalise beyond the specific situation of each, instead aiming to generate propositions grounded in the context of each institution's unique local situation, as described by Punch (2014, p. $22,33,123)$.

Where possible without impinging on participants' confidentiality, I have presented indicative quotations and illustrative stories, to maintain the kotahitanga/unity of individual stories and experiences by placing concepts in context, and to illustrate respondents as whole people, as in Szekely et al. (1997).

\section{Results and discussion}

Interview participants' responses to the research sub-questions listed in Appendix 4 showed an impressive diversity of approaches taken by different libraries to tailor their services and priorities to their own users' requirements, although there was strong agreement on some matters.

1. Who is adding the MSH terms, how, and with what support/guidance? (Cataloguing/indexing/arrangement and description)

\section{a. Staff with responsibility for applying terms.}

In most larger libraries, a small number of metadata librarians were responsible for adding MSH terms to records, although in one metadata team, all team members were empowered to do this, with collegial support and some supervision from a Māori specialist. In some smaller libraries, Māori specialist librarians themselves shared this task. 


\section{b. Competency and confidence.}

Even these specialist staff hesitated to declare themselves fluent in te reo Māori, often modestly prefacing the word "fluent" with a heavily emphasised "relatively" or "reasonably". However, some were able to offer library service in te reo to their users, which was especially appreciated by those in full immersion learning situations. Others found that library users with greater fluency supported them with te reo, as they reciprocally supported their users with research. In several libraries, all staff were encouraged to develop further in te reo, and one participant was undertaking advanced studies through a wānanga.

Both Pākehā and Māori participants articulated the importance of understanding not only te reo, but also "the holistic concepts of how Māori knowledge is organised and treated - the tikanga and the kawa". Tikanga and kawa are sometimes explained as inter-related aspects of cultural knowledge of the right ways of doing things (Ka'ai et al., 2004, p. 173; Marsden, 2003, p.66; Māori Subject Headings Working Party, 2000; Mead, 2003, pp. 7-8, 11-20; Te Aka Online Māori Dictionary, n.d.).

Some Pākehā participants who had studied te reo, but considered themselves less than fluent, felt uncomfortably isolated when they were consulted for advice by other colleagues who had even less learning, as they felt that their knowledge was inadequate to fulfil expectations. They identified an ethical dilemma in the situation - should they refuse to respond, to highlight the resource limitations within their organisation? They believed that their level of fluency in te reo would not be considered acceptable for someone cataloguing in English, and that their library should have staff with these skills. "If we really are serious about making 'a structured path to subjects' for Māori customers, then we should have somebody with those skills."

The experiences of those participants who were dedicated metadata librarians indicated that there may have been some improvement in this area in the ten years since Simpson et al.'s study (2005, p. 94-95) identified a lack of Māori language experience among cataloguers as a concern, but there is still some way to go, and there remain very few Māori staff who are trained metadata librarians.

On a positive note, however, some Pākehā metadata librarians expressed cautious confidence in their application of MSH terms, with the benefit of experience and ongoing guidance from their colleagues. 


\section{c. Criteria for adding terms.}

Some librarians added MSH terms to everything they catalogued, and were amazed to hear that other libraries applied selection criteria. "It shouldn't have to just be about Māori to deserve a Māori subject heading. It should be that you just want to open it to all of those people who are interested in using te reo Māori." These librarians' aim in adding MSH terms to all material is that their users will be able to search just once, in one language - te reo or English - and find all the material they need.

Others would like to be able to do this, although policy and/or resource constraints impose restrictions. One participant quoted the kaupapa of the MSH, as stated on its website: "The purpose is to provide a structured path to subjects that Māori customers can relate to..." (Te Whakakaokao, 2013), implying that the terms could be applied to a very wide range of subjects. However, one participant noted that a positive result of selectively applying the terms is that the MSH can act to bring together diverse Māori material, helping to achieve one recommendation from Irwin \& Katene's (1989) paper and from Szekely \& NZLIA's (1997) hui - "the ability to browse Māori collections without the separation engendered by foreign classification systems".

Several libraries which did apply selection criteria applied MSH terms only to resources with a minimum of $20 \%$ of the content in te reo Māori or about Māori topics, following the policy of the National Library (East et al., 2007; Morehu et al., 2009). Some also used MSH terms if a Māori author or donor had been identified, and some also applied MSH terms to works with information of local relevance, information specific to a particular iwi or area, or topics which were important to their users' endeavours, such as native flora and fauna or social issues relevant to universities' Māori Studies courses. Many libraries used copy cataloguing to save staff time, copying records from the National Union Catalogue (NUC) into their own catalogues via the Te Puna service, so the National Library's policies had a strong influence on which records had MSH terms attached in their catalogues. New records might be created only for local works, such as theses produced within a university.

However, any 20\% minimum was usually interpreted liberally, especially for material with Aotearoa New Zealand content. For example, if little other information was available on a topic or it seemed especially important for some other reason, MSH terms might be added even if less than $20 \%$ of the content meets the above criteria. This was especially important to highlight hard-to-find 
information, not only for discoverability, but also to prevent undue weeding. This flexibility also aligns with the National Library's approach.

Some libraries had developed methods for circumventing limitations imposed by policy or technology, to add subject headings outside of their catalogues' subject heading fields. This allowed them to use terms which were not yet part of the MSH thesaurus, and also allowed staff other than metadata librarians, such as Māori specialist librarians, to contribute their knowledge directly to the catalogue. "Our catalogue has become a very collaborative mechanism." Strategies included adding terms in contents notes or abstracts, and tagging records via discovery layer software. One library tagged records with common misspellings and alternative spellings of terms, based on regular checks of the discovery layer's failed search reports. "No record is ever complete. There's always something you could add or change to make it more accessible."

None of the participating libraries had an ongoing program of retrospective cataloguing, although some had completed projects of retrospective cataloguing in the past, targeting specific collections or records which included certain Library of Congress subject headings, and one library's current business plan included assessing the feasibility of such a project. Many participants enriched older records with MSH terms on an ad-hoc basis, sometimes in response to specific requests for access, but it was not the general practice in any participating library. Resource or time limitations were often cited as preventing retrospective addition of MSH terms - higher priorities included interacting directly with library users, expanding collections "to provide our resources that will support our own knowledge of ourselves", and fulfilling requests. Some libraries' collection policies were focused on current rather than historic material, therefore retrospective cataloguing was gradually obviated by the turnover of the collections. Several libraries were proud to say that they had begun adding MSH terms as soon as the thesaurus became available, but this meant that many new terms had become available since they had first applied terms to records, and these new terms had not been systematically added to older catalogue records. There was concern that, as noted by Simpson et al. (2005, p. 104), this was limiting the discoverability and therefore the use of some items.

One of the big things is the more we promote the use of the Māori Subject Headings, the more the issue of the fact that not all of the relevant resources are described using those subject headings becomes more of a problem - but it also then becomes a reason for acting to actually change that. 


\section{d. Collaboration between metadata and Māori specialist librarians.}

As previously noted, metadata librarians and Māori specialist librarians were sometimes the same people. In other libraries, staff supported each other in a number of ways. In some teams, all newly created records were routinely checked by “buddies", and one library's Māori specialist librarian had a policy of checking new records for her colleagues, noting that the quality and consistency of the MSH terms attached had improved so significantly over time that she was phasing out this work. One library's metadata staff received training from a Māori specialist librarian in response to queries or upon joining the team. Some metadata librarians were reluctant to consult their colleagues too frequently, as they did not wish to overburden staff with specialist skills, but all participants who had received these enquiries stated that they had been pleased to be consulted and to have been able to help.

Participants from certain organisations reported particularly relaxed and productive relationships between metadata and Māori specialists, who frequently consulted each other. Several factors facilitated this. Physical proximity was one. "She's just through the door." Taking time for informal opportunities for relationship building was also helpful - one Pākehā participant described her library's waiata group as an important way to connect with colleagues. "It's brought in people from outside the Library as well. It's growing, it's strong, it's such fun." An overall approach of respect and appreciation was also crucial - never rushing or demanding things of colleagues, but negotiating.

- I know that they're the experts, so it's about communicating and saying "Can you do this? How do you do this?". "Is it possible?" is my favourite saying.

- It's about being flexible, building the relationship. It is about respect, and knowing that people have got skills beyond what you can do.

- Whanaungatanga; it's about sharing. And knowing that wherever you are within the Library, there are people with skills - skills that you can use.

A common theme was the diversity of a Māori specialist librarian's role. Participants who were Māori specialist librarians often had many responsibilities within organisations of all sizes - working directly with diverse library users, preparing learning materials, adding metadata, contributing to policy development, and more. There are challenges as well as advantages in this when seeking to make the most of the MSH resource. These specialists' diverse skills, broad viewpoints and ability to build connections are valuable, but there are many demands on their time and energy, as other 
researchers have documented through the decades (MacDonald \& NZLIA, 1993; Parekowhai \& Black, 1990; Simpson et al., 2005).

- Learning about the Subject Headings... how does it fit into the bigger picture for us as Māori services... Our kaupapa is actually really big [as Māori specialist librarians] and so I still feel as if I'm at kohanga reo stage within the Library, and so I want to sort of just widen it...

- We used to have joint meetings. People had to introduce themselves and their roles - "I'm a business librarian", "I'm a health librarian". When it came to me, I would point to each one and say, "I do your job, your job, your job, oh - and your job. I do undergrad and postgrad, everything Māori." 'That's the scope of the role.

\section{e. Seeking support from colleagues outside the library.}

Few participants reported looking outside of their organisations for guidance, although Te Rōpu Whakahau was praised for their dissemination of information about the MSH. Some participants had emailed enquiries and suggestions to the MSH team via the website, although they did this less frequently as the thesaurus developed. "We seem to be lucky in that they seem to be slightly ahead of us ... the [terms] that we want are there." Participants were likely to consult on-site colleagues first. However, some participants had never considered contacting Te Whakakaokao with queries, and were unaware that the development of the thesaurus is driven by such requests (East et al., 2007; Morehu et al., 2009; Paranihi, 2011b), following the recommendations of Simpson et al. (2005, pp. 104; 106).

\section{f. Hopes for additional support.}

When asked what further help they would like, participants responded with great consistency.

Participants in almost every interview wanted more training, including continuing support, and were eagerly anticipating the forthcoming scheme for metadata and reference librarians from Te Whakakaokao, in alignment with Simpson et al.'s (2005, p. 106) recommendations for education and promotion to support the use and development of the MSH. Participants hoped that the new program would increase their confidence, show more options for ways to use the MSH, raise awareness among librarians, and offer ways to promote the MSH among colleagues, researchers, and library users: "whanau, hapu, iwi - and not just to Māori!" 
Many participants wished to exchange knowledge across libraries, which may be buying and simultaneously describing the same works - "not having to reinvent the wheel". Connections between libraries with similar user groups or between libraries with special knowledge, such as those with strong local or tribal information collections, would be particularly valuable. Certain libraries, such as Porirua City Library and Auckland Libraries, were known for excellence in applying MSH terms to records, and some participants occasionally consulted the catalogues of these libraries for comparison, but none had established a systematic way to find out when a library had updated its records. In the absence of such a system of information sharing, the interview questions of this research seemed to act as a sort of one-off exchange of ideas, perhaps because the questions had been developed after discussion with experienced and interested information professionals. Several participants said they were looking forward to seeing the results of this research, to learn more about others' experiences.

All advocated energetically for further development of the MSH thesaurus, and this was such a strong theme that it will be addressed separately in this report.

\section{g. Using the MSH website.}

There was similarly uniform agreement about the features of the MSH website (http://mshupoko.natlib.govt.nz/mshupoko/index.htm). Participants liked the whakamārama and scope notes, related terms and near terms, alphabetical list of terms, linkage between terms, and bilingual presentation of both English and te reo Māori, with hover-over English explanations for newer terms in te reo. All of these features were repeatedly described as particularly helpful for staff who are not yet fluent in te reo, suggesting that these aspects of the MSH site design and structure are helping to achieve the inclusiveness proposed by the participants in Simpson et al.'s hui (2005, pp. $62-63,87,106)$.

Suggested improvements for the site included easier searchability, including a "Google-like" keyword search function, hover-over for older terms to match the newer ones, automatic presentation of Māori terms connected with English terms, an easier way to view whakamārama or scope notes, a different default sequence of presentation of the terms for those who never use the top terms which are currently presented first on the website, a way to view a full list of terms in te reo only, a generally less "clunky" interface, and a more attractive and up-to-date appearance. The 
website has not changed in many years, yet some participants affectionately listed its very simplicity and familiarity as advantages.

\section{h. Contributing to the National Union Catalogue (NUC).}

The participating libraries did not add MSH terms to existing records in the NUC. Smaller libraries often had cheaper subscriptions to Te Puna's WebCat, which did not allow the librarians to add subject headings directly to records. However, any libraries which did perform original cataloguing used Te Puna, thus contributing new records to the NUC, sometimes with MSH terms attached.

\section{i. Externally supplied terms.}

No libraries which participated in this study were outsourcing their cataloguing, which is unsurprising since all were invited to participate because they were actively applying MSH terms. However, some catalogue records were externally supplied, such as OCLC records used for copy cataloguing of overseas material, and groups of records supplied with ebook collections.

Participants did not expect to see MSH terms on these records originating from outside of Aotearoa New Zealand. Records created by the National Library were also selected by several libraries when copy cataloguing from the NUC, and some participants also looked for MSH terms in the publication data shown on items, especially those from publishers such as Huia which print MSH terms on items, drawn from the cataloguing data supplied by the National Library through their Cataloguing-In-Publication programme.

\section{Selecting terms for users.}

Few participants were tailoring their selection of MSH terms to specific user needs. Most explained that their user communities were broad, and that one item could be relevant to many users for different reasons over time. "The challenge with Māori research and Māori teaching and learning is that multidisciplinary approach to things."

However, in one special library, items were purchased in response to user requests or known areas of interest, so terms were applied with those particular users in mind. Other libraries made special efforts to accentuate local information. Some libraries considered educational curricula even if they were not based within education institutions - one Māori specialist librarian had previously developed relationships with local kura kaupapa and wānanga whose students used public libraries 
during their studies, and another library made a point of considering national curricula when cataloguing juvenile literature.

\section{How are librarians using the MSH terms and thesaurus when searching with users? (Reference \& research services)}

\section{a. Staff awareness.}

From several of these libraries, more metadata librarians than customer-facing staff participated in this study, so it would be easy to underestimate the awareness of the MSH among frontline staff. All Māori specialist librarians in the participating libraries were aware of the MSH, but participants from some libraries had an impression of a low level of awareness among their colleagues. One participant noted that the MSH were not mentioned in any staff training material. Another suggested that although most of her colleagues were probably aware that there are subject headings in te reo attached to records, they might not realise that the MSH is a discrete thesaurus. Others perceived that many staff were aware of the MSH but not using them to answer enquiries, because they tended to refer all reference enquiries on Māori topics to the specialist librarians. Following Grace's (1994) principle of developing professional strength through partnerships, one librarian's team was working to overcome this reticence, encouraging their colleagues to try more research strategies before referring on.

I think they should give it a go ... What it does for them is expand their kete [basket of knowledge]. It is improving - it could be better though. We chip away at that, and that is about investing in the subject librarians themselves; it's about giving them confidence.

Further initiatives to increase awareness were underway at other libraries. One library's staff catalogue interface showed MSH terms highlighted to distinguish them from LCSH terms. Some metadata librarians had asked to spend some time at the enquiries desk. One participant had written a staff blog post about the MSH, and had followed this up with an email to all staff. One Māori specialist librarian had organised a staff development group project, open to any interested library

staff, to build connections and increase staff confidence in searching for Māori material.

\section{b. Staff search strategies.}

Staff who did use the MSH while searching tended to do this via keyword searches, as this was the default option in several libraries' staff and user catalogue interfaces. An initial keyword search might begin without particular reference to the MSH, but staff might then follow a link from an 
MSH term to find further resources. However, participants pointed out that staff could be using the MSH without realising it, as their keyword searches benefit from the presence of the MSH terms.

\section{c. An intercultural interface.}

The MSH acts as a cultural interface (Paranihi, 2013; Paewai \& Reweti, 2014) in several ways. Firstly, at some libraries, many users are already expert in searching for Māori information, and their enquiries are often about finding information on international or non-Māori contexts. Following the philosophy of “don't teach me about my culture, but use my culture to teach me” (Lal \& Walker, 2014), Māori specialist librarians sometimes suggest that library users whose reo is strong can try using the MSH to find English language terms for Māori concepts, to help them search the catalogue or databases. This can be more efficient than using a dictionary to translate terms in these situations because it identifies which of several synonyms or related terms are actually used in the library catalogue. "It's a starting place." Words cannot always be translated between languages - at least, not succinctly - but the MSH thesaurus is one tool which can help. "I do that all the time. I like it! It's a learning thing." The opposite is also potentially true - library staff with less confidence in te reo could use the MSH to understand or frame their users' requests - although no participants reported using the MSH in this way.

I thought as a tool it was a useful way into the use of te reo Māori because it's directly applicable to searchers, and when used, it's going to bring up useful results. But no, we don't. It's not in any of the training that we do.

Secondly, knowing that the MSH exist can encourage students that it is possible to search in te reo Māori; and thirdly, metadata librarians comment that they learn a lot about tikanga Māori and te reo Māori by using the MSH, and that colleagues are interested to learn more.

\section{How are libraries displaying the MSH to users, and supporting/guiding their use? (Independent searching)}

\section{a. Catalogue access.}

MSH terms were visible on item records in the online catalogues and discovery layers of all participating libraries, although they were less prominent with some software, and macrons were not always displayed successfully. One library's catalogue could be viewed and searched in te reo, although not through its discovery layer. Catalogue records contributed to the NUC are also shared 
internationally, as the NUC's records are accessible through the international union catalogue OCLC.

In one specialist library, with long-serving specialist staff members, the current staff knew the collection so well that they could often identify relevant resources to answer reference enquiries without recourse to the catalogue. Similarly, library users were more likely to consult librarians than the catalogue. The library manager encouraged this, because it was often more efficient in that context.

Their time ... is very limited. I don't want the exercise of trying to find information to be frustrating or laborious because they need to use the catalogue to find things. I'd much rather that they come to me and I can give them the information straight away. It's because they're time poor. In saying that, I do have plenty of time to show them the library, and if they say "I want to use the catalogue", if they want to go that step further, I'm more than happy to help them with that ... They might know what they're looking for, but they're not sure how to word it. I've found that many times. You ... have to have a conversation.

\section{b. Research guides.}

Only one library promoted the MSH through research guides, online or on paper, although another participant was also considering adding a link to the MSH website to her library's Māori subject guide. Face-to-face training was considered a vital complement to any such written information. "Until you tell people and show people why it's useful, they just see it as something else on a long list of resources that they might think about using."

\section{c. Information literacy education.}

Several participants included information about the MSH in information literacy sessions, whether in one-to-one induction or orientation sessions, individual or small group research consultations, class teaching sessions, public seminars and presentations to interested groups, or online training incorporating screen sharing software so that library users and librarians could take turns demonstrating or trying out procedures. "Really important to broaden their horizons."

\section{d. On-site signage.}

Some libraries displayed MSH terms on shelf labels, although shelving rearrangement sometimes temporarily disrupted this. One library was developing bilingual signage throughout the building. Another library was in the process of planning lists of topics to be displayed on the end of each 
range of shelves, with higher level LCSH terms matched with similar MSH terms, in the hope of introducing the MSH terms to more library users to encourage them that it is possible to search under these terms.

\section{The most consistently recurrent themes emerged in response to the most open question I} asked: "What else is important to share?".

\section{The importance of the MSH.}

Many enthusiastic comments reflected recognition of the value of the MSH for useful and respectful description of information resources.

- "We know it enriches everybody's life."

- 'There's been commitment to it since it started, because of the idea that if you're going to be talking about Māori topics, it's useful to use words and phrases Māori are going to want to use."

- "It's about discoverability."

- 'The good thing is that it's a way for Māori to describe themselves more accurately, and I think that was the whole purpose of the Māori Subject Headings, being able to describe ourselves, in our culture, from our own perspective and our own viewpoint, and not from a Pākehā perspective - you know, Pākehā describing our culture? So that's what I really loved about that whole kaupapa, Māori Subject Headings. And the Pākehā words didn’t describe us accurately at all." [emphasis definitely in the original]

- 'I really support this project's kaupapa of Māori Subject Headings. I think it’s great. It's great because it's what we needed to do within libraries. We definitely support using these terms ..."

Participants noted that the MSH can support language revitalisation, which was one of the early aims of the project as specified by Simpson et al. (2005, p. 105). "Our cataloguers are promoting te reo Māori." The importance of this work is acknowledged by LIANZA, which affirms that te reo Māori is "vital to the identity and survival of Māori as a people" (Library and Information Association of New Zealand Te Rau Herenga o Aotearoa (LIANZA), n.d.; Lilley \& Paringatai, 2014).

Study participants likewise recognised the value of the MSH for speakers of New Zealand English. “We've always talked about Library of Congress Subject Headings doesn’t even approach different English cultures, because it is very American.” For example, the LCSH uses words such as 
"railroad" (versus New Zealand English "railway"), and for waka uses "Canoes-Oceania", thus linking two words which many information seekers in Aotearoa New Zealand would not think to use, and also probably missing the sense in which "waka" can refer not only to various types of travelling vessels, but also to the peoples descended from the crews of the exploring waka from Hawaiiki.

\section{The importance of resourcing the MSH to develop further.}

All thesauri must be continually extended and reviewed to remain relevant. "Library of Congress isn't the be-all and end-all of American culture either, is it?" All participants hoped for more and faster development of the thesaurus, including contemporary terms reflecting the ongoing evolution of te reo Māori in a changing world, more specific terms to accurately reflect subdivisions of academic research areas, and also terms which were less academic for use by nonspecialist information seekers. The consistency of these responses implies that ongoing effort and resourcing is required to meet Irwin and Katene's (1989) and Simpson et al.'s (2005, pp. 62-63) hopes for a more granular, intuitive and inclusive classification system.

"We did it as a way of describing ourselves and our own perspective and our own worldview, but ... When I look at the Māori Subject Headings, I'm thinking . . . a person off the street is not going to use that term to look for what they want ... and I think that was the problem with the Pākehā subject headings too; they were using terms that Māori would never think of using if we went on the catalogue to try to find Māori books." One comment on this theme inspires a hopeful thought - the broader revitalisation of te reo Māori may in time help to bridge the gap between literary and everyday reo, as more speakers of te reo Māori recover fluency across a variety of contexts.

"Some of the things that we struggle with in English, we have that same problem in Māori, that the term's too technical, or the term's not known widely enough. That's what I'm thinking - the term's not known widely enough."

Better resourcing is required to allow the progress of the MSH to match the national and international excitement associated with its launch. Participants recommended that Te Whakakaokao should meet more than three times yearly, with paid release from work for the members (who currently donate their time voluntarily), that the team's researcher should be given more time and closer connections with librarians, and that scholarships should be provided to attract students with relevant skills in tikanga and te reo to the profession and to the team. 'It's a positive 
thing for New Zealand that we should be celebrating by putting funds into it." It was considered that the National Library would not be fulfilling its responsibilities under the National Library Act if adequate resources were not put in to this work. "... if they continue to call themselves the 'National Library', they have to support these national projects. The interviewer is nodding furiously here [laugh]!"

\section{Conclusions}

As I worked to integrate the above wealth of knowledge contributed by interview participants in response to my many interview questions, I began to suspect that by asking questions which were less specific, I could have allowed participants more freedom to share their knowledge, and I wondered how these experts might have guided our conversations if I had simply asked the four over-arching questions implied by the study objectives:

- What is working well?

- What could work better?

- What are the benefits of this work?

- What further questions do we need to answer?

Yet answers to these broader questions do emerge.

\section{What's working well for librarians and library users? What factors and processes are enabling success?}

Some libraries were fortunate to have attracted and retained staff with expertise in te reo and in tikanga Māori, who add MSH terms to records or guide others in their application. Where flexible technological systems allowed it, these specialists were able to enrich records even when not employed as metadata librarians; and in environments conducive to relaxed communication, they could support cataloguing work even if they did not directly add terms themselves. Effective communication was fostered by physical proximity, and also by the creativity and commitment of staff, who built relationships over time by sharing decision making, setting up joint projects, creating opportunities to learn and have fun together, and approaching each other with respect.

Many other participants who felt less confident in te reo were committed to advancing their skills. 
Certain libraries were applying MSH terms to all catalogue records, while those with more limited capacity applied their policies with flexibility, to maximise discoverability of the most crucial materials.

Several features of the MSH website facilitate application of MSH terms. Whakamārama and scope notes, connections between terms, hover-over explanations and the alphabetical index were all firm favourite features. Some libraries supplemented these useful elements with in-house written guidance, and several had contacted the MSH team for personalised advice, thus also contributing to further development of the thesaurus with their requests or suggestions.

Librarians were promoting awareness of the MSH to library users in many ways - connecting the terms to resources visually with shelf labels, explaining their uses during search strategy education and public seminars, and reinforcing face-to-face training with written study guides.

\section{What good things do we see happening because the MSH are available?}

Unfortunately, I did not specifically ask this question during interviews. Some examples of the observed benefits of the MSH were gathered nonetheless, but this is a potentially fruitful area for further research.

Metadata librarians reported that their work with the MSH had expanded both their understanding of and interest in te reo and tikanga Māori. Participants noted that the MSH promote respect and understanding of these taonga/treasures among information seekers within Aotearoa New Zealand and internationally.

The MSH help librarians and library users to find useful search terms in both English and te reo when information seekers are most confident in te reo, and the existence of the MSH encourages library users to incorporate te reo in their searching.

\section{What could work better? What are the barriers? What would make it easier for library users to benefit from the MSH?}

Participants unanimously indicated a wish for ongoing and accelerated development of the MSH thesaurus, to keep it up to date with current language use and enrich it with adequately specific terms. Stronger resourcing for the MSH team was advocated, coupled with wider awareness that 
requests and suggestions from practising librarians are required to support the team to direct their efforts appropriately.

Many participants wanted more support to fully utilise the resource, and to promote awareness among colleagues within their organisations and across the profession, as well as library users and potential users throughout the community. They also wanted continuing guidance, including information sharing across libraries. There were high hopes for Te Whakakaokao's training programme.

Several participating librarians expressed strong desire for better understanding of te reo and tikanga Māori, and especially for improved recruitment of staff with these skills.

Time limitations prevented some libraries from using the MSH as extensively as their staff would like, particularly in relation to retrospective cataloguing.

Improvements to the MSH website were suggested, including addition of a search function, as well as efficiency enhancements such as extension of the popular hover-over function or quicker access to the very useful whakamārama and scope notes.

\section{Implications and suggestions for further research}

This study has explored the implementation of the MSH within selected research libraries in the Te Upoko o te Ika / Wellington region. A broader view encompassing other types of information organisations and memory institutions, or quantitative analysis of the proportion of institutions which are and could be actively engaging with the MSH, awaits a larger project.

This research has not investigated the appropriateness of MSH terms selected for records, but the misgivings of some metadata librarians who participated may indicate that questions such as accuracy, specificity, or relevance to user requirements may be of interest to future researchers. For example, Simpson et al., (2005, pp. 100-101) noted that metadata related to place can be especially important to Māori information seekers.

The study was also unable to encompass assessment of library users' opinions and interactions with the MSH, although the analysis of one library's search log data conducted during the preparatory phase did indicate that information seekers were using MSH terms in free search situations. Discussions with library users are recognised as a necessary ingredient in forward planning by the 
current members of the Māori Subject Headings Working Group and by previous writers on the subject, including MacDonald \& NZLIA (1993) and Ta'ala (2008), as mentioned in the "Population and sample" section of this report.

Any of these types of research could assist in planning ongoing training for library staff or users, and the development of an information sharing network for library staff could in itself be an opportunity to investigate the best ways to share experiences and specialist knowledge, such as local, iwi, cataloguing or MSH expertise.

Another topic which is currently attracting much interest - though it is not a new issue (Morehu et al., 2009) - is the potential to expand the MSH thesaurus to cover all topics, including those beyond te ao Māori / the Māori world. Simpson et al. (2005, pp. 67-68; 99) recommended that the thesaurus should include terms "for all collections" and "support study at all levels and for all disciplines", and this has been endorsed recently by Te Rōpū Whakahau (Te Rōpū Whakahau, 2015b). Such a bold initiative could support information seekers to search efficiently in te reo Māori, opening search pathways for library users such as recent generations of kura kaupapa students, who are already relatively knowledgeable in mātauranga Māori and wish to explore other global perspectives for comparison. But to make this vision into reality would require consideration of various conceptual and practical issues. One is how to respect and maintain the integrity of different belief systems - perhaps using allied thesauri, in the same way that recognition is given to the MSH as a parallel thesaurus alongside the LCSH. Another is how to supply the resources required for such extensive development of the thesaurus. Library staff would then require resources to learn to use the augmented thesaurus, as well as extra time to apply the increased number of terms included. A third question is whether users would benefit from a filter to distinguish Māori collections from non-Māori, as currently the MSH can work as a filter in libraries which only apply MSH terms to works meeting certain criteria. Simpson's hui participants (2005, pp. 71) requested this function, advising that although the thesaurus should include terms for all subjects, it should also enable information seekers to search specifically for works on Māori topics when appropriate.

Having completed this research, my priority is now to restore the knowledge collected to all contributors, including the interview participants as well as those within Te Whakakaokao / the Māori Subject Headings Working Group, the Māori Subject Headings Governance Group, and Te 
Rōpū Whakahau's Te Ūpoko o te Ika rohe/region, who have so graciously offered their encouragement and advice. This report, and the conversations which helped me to write it, will return to contributors, and I hope that the shortcomings and limitations of this small-scale student project will encourage further research and discussion, for as previously outlined in the "Research question and implications for research design" section of this report, and in Appendix 2, there are many areas which remain for investigation.

As Garraway \& Szekely said in 1994, Ka Mahi Tonu ("work will be ongoing”, or in their words: "we are still working on it!").

\section{Iti noa ana, he pito mata.}

Although this is only small, more may sprout from it. 


\section{References}

Amey, C. (2012). Ngā Ūpoko Tukutuku: Building a house with the right words | Blog | National Library of New Zealand. Retrieved from https://natlib.govt.nz/blog/posts/nga-upokotukutuku-building-a-house-with-the-right-words

Barlow, C. (1991). Tikanga whakaaro: Key concepts in Māori culture. Auckland, N.Z: Oxford University Press.

Bishop, R. (2005). Freeing ourselves from neocolonial domination in research: A Kaupapa Māori approach to creating knowledge. In N. K. Denzin \& Y. S. Lincoln (Eds.), The SAGE handbook of qualitative research (3rd ed, pp. 109-138). Thousand Oaks: Sage Publications.

Bundy, A. (2004). Australian and New Zealand Information Literacy Framework: Principles, standards and practice - Ako Aotearoa. Retrieved May 19, 2014, from http://akoaotearoa.ac.nz/community/ako-aotearoa-suggestedresources/resources/pages/australian-and-new-zealand-information-li

Cecez-kecmanovic, D. (2011). Doing critical information systems research: Arguments for a critical research methodology. European Journal of Information Systems, 20(4), 440-455. http://doi.org/http://dx.doi.org.helicon.vuw.ac.nz/10.1057/ejis.2010.67

Coleman, M., \& Marshall, G. (2014). Wānanga libraries. In L. Stone (Ed.), Informing New Zealand - He puna whakamōhio mō Aotearoa. 6th edition. Lower Hutt, N.Z.: Open Polytechnic. Retrieved from http://informingnewzealand.wikispaces.com/Libraries+-+Wananga

De Barry, H. J. (1998). Process of creating subject headings in Te Reo Maori. Victoria University of Wellington, Wellington, N.Z. Retrieved from http:/ / restrictedarchive.vuw.ac.nz// handle/123456789/7881

East, R. (2008). Indigenous subject access: Ngā Ūpoko Tukutuku, Māori Subject Headings (pp. 3767). Presented at the Australian and New Zealand Theoretical Library Association (ANZTLA), Wellington, N.Z. Retrieved from http://www.nla.gov.au/openpublish/index.php/ANZTLA/article/view/2142/2547

East, R., Keats, J., \& Reweti, A. (2007). Ngā Ūpoko Tukutuku \& the Iwi-Hapu Names List (Ngā Ūpoko Tukutuku/Māori Subject Headings Report, March 2007). Presented at the Te Rōpū Whakahau Hui-ā-Tau 2007, Eke Panuku! Eke Tangaroa!, Takapūwahia Marae, Porirua, N.Z.: Te Rōpū Whakahau.

East, R., \& Staincliffe, P. (2007). Cataloguing Māori materials. Librarylife, 313, 16-18. 
Garraway, J., \& Szekely, C. (1994). Ka mabi tonu: Biculturalism in New Zealand librarianship, 1992-1994. Wellington [N.Z.]: Published by the N Strategy Bicultural Actions Group in association with the New Zealand Library and Information Association.

Ghaddar, J., \& Caidi, N. (2014). Indigenous knowledge in a post-apology era: Steps toward healing and bridge building. Bulletin of the American Society for Information Science and Technology (Online), $40(5), 41-45$.

Grace, D. (1994). Bicultural development. In J. Garraway \& C. Szekely, Ka mabi tonu : biculturalism in New Zealand librarianship, $1992-1994$ (pp. 6-7). Wellington, N.Z.: N Strategy Bicultural Actions Group and New Zealand Library and Information Association.

Hayes, L. (2013). Kaupapa Māori in New Zealand public libraries. NZLIMJ, 53(2). Retrieved from http://www.lianza.org.nz/kaupapa-m\%C4\%81ori-new-zealand-public-libraries

Hudson, M. (2010). Māori Health Research | Health Research Council. Health Research Council of New Zealand: Māori Health Research. Retrieved from http://www.hrc.govt.nz/news-andpublications/publications/maori

Irwin, K., \& Katene, W. (1989). Maori people and the library: A bibliography of Ngati Kabungunu and Te Waka o Takitimu resources. Wellington, N.Z.: He Parekereke, Dept. of Education, Victoria University of Wellington.

ISO (International Organization for Standardization). (2011). ISO 25964-1:2011 - Information and documentation -- Thesauri and interoperability with other vocabularies -- Part 1: Thesauri for information retrieval. Geneva, Switzerland: ISO (International Organization for Standardization). Retrieved from http://www.iso.org/iso/catalogue_detail.htm?csnumber=53657

Johnston, L. (2007). The role of libraries and archival collections in the preservation and revitalisation of indigenous knowledge: The case of revitalisation of te reo Māori. New Zealand Library \& Information Management Journal, 50(3), 202-215.

Ka'ai, T., Moorfield, J. C., Reilly, M. P. J., \& Mosley, S. (Eds.). (2004). Ki te whaiao: An introduction to Mãori culture and society. Auckland, N.Z: Pearson Longman.

Lal, M., \& Walker, J. (2014). What can mainstream libraries learn from Te Pātaka Māramatanga - an indigenous academic library? Lessons from Wānagogy. Presented at the LIANZA, Auckland, N.Z. Retrieved from http://www.lianza.org.nz/mohan-lal-and-jock-walker-whatcan-main-stream-libraries-learn-te-p $\% \mathrm{C} 4 \% 81$ taka-m $\% \mathrm{C} 4 \% 81$ ramatanga-indigenous 
Library and Information Association of New Zealand Te Rau Herenga o Aotearoa (LIANZA). (n.d.). BOK 11 - Awareness of Indigenous Knowledge Paradigms | LIANZA. Retrieved May 1, 2015, from http://www.lianza.org.nz/bok-11

Lilla: International Women's Network. (n.d.). Lilla Watson | About. Retrieved from https:/ /lillanetwork.wordpress.com/about/

Lilley, S. C. (2013a). A bicultural evaluation of New Zealand public library websites. NZLIMJ, 53(1). Retrieved from http://www.lianza.org.nz/resources/lianza-publications/nzlimj/biculturalevaluation-new-zealand-public-library-websites

Lilley, S. C. (2013b). Te Rōpū Whakahau: waiho i te toipoto, kana i te toiroa, celebrating 20 years 1992-2012. Wellington, N.Z.: Te Rōpū Whakahau.

Lilley, S. C. (2012). Māori information sources and services: Delivering a reference course that meets the needs of Māori clients. The Reference Librarian, 53(1), 67-75. http:/ / doi.org/10.1080/02763877.2011.596087

Lilley, S. C., \& Paringatai, T. P. (2014). Kia whai taki: Implementing indigenous knowledge in the Aotearoa New Zealand library and information management curriculum. Australian Academic \& Research Libraries, 45(2), 139-146. http://doi.org/10.1080/00048623.2014.908498

MacDonald, T., \& New Zealand Library and Information Association. (1993). Te Ara Tika: Mäori and libraries: a research report. Wellington, N.Z.: New Zealand Library \& Information Association.

Macnaught, B. (2012). The National Library of New Zealand: The New Generation National Library Strategy. Alexandria, 23(1), 1-13.

Maina, C. K. (2012). Traditional knowledge management and preservation: Intersections with Library and Information Science. The International Information \& Library Review, 44(1), 13-27. http://doi.org/10.1080/10572317.2012.10762911

Māori Subject Headings Working Party. (2000). Māori Subject Headings Working Party report to LIANZA / Te Rau Herenga o Aotearoa and to Te Rōpü Whakahau. Retrieved from http:/ /www.trw.org.nz/publication/

Māori Subject Headings Working Party. (2001). Māori Subject Headings Working Party report to LIANZA / Te Rau Herenga o Aotearoa and to Te Rōpü Whakahau: Phase Two. Retrieved from http://www.trw.org.nz/publication/

Margaret, J. (2013). Working as allies: Supporters of indigenous justice reflect. Auckland, N.Z.: AWEA (Auckland Workers Educational Association). 
Marsden, M. (2003). The woven universe: Selected writings of Rev. Mäori Marsden. (T. A. C. Royal, Ed.). Otaki, N.Z: Estate of Rev. Māori Marsden.

Mead, S. M. (2003). Tikeanga Māori: living by Māori values. Wellington, N.Z: Huia.

Mertens, D. M. (2003). Mixed methods and the politics of human emancipation: The transformative-emancipatory perspective. In A. Tashakkori \& C. Teddlie (Eds.), Handbook of mixed methods in social \& behavioral research (pp. 135-164). Thousand Oaks, Calif: SAGE Publications.

Mertens, D. M. (2009). Transformative research and evaluation. New York: Guilford Press.

Mertens, D. M. (2011). Disability communities: Transformative research for social justice. In N. K. Denzin \& Y. S. Lincoln (Eds.), The SAGE handbook of qualitative research (4th ed, pp. 227241). Thousand Oaks, Calif: Sage.

Mertens, D. M. (2012). Transformative mixed methods addressing inequities. American Behavioral Scientist, 56(6), 802-813. http://doi.org/10.1177/0002764211433797

Moorfield, J. C. (2003). whakapapa - Te Aka Māori-English, English-Māori Dictionary. Auckland, N.Z.: Te Whanake. Retrieved from http:/ / www.maoridictionary.co.nz/search?idiom $=\&$ phrase $=\&$ proverb=\&loan $=\&$ keywords =whakapapa

Morehu, A., Ta’ala, T., Gutchlag, K., \& Stretton, C. (2009). Māori Subject Headings workshop. Presented at the LIANZA Conference 2009 - He Tangata, He Tangata, He Tangata, 12-14 October, 2009, Christchurch, N.Z.: Library and Information Association of New Zealand Aotearoa (LIANZA). Retrieved from http://www.lianza.org.nz/m\%C4\%81ori-subjectheadings-workshop

Murray, K., \& Barnett, J. (2007). Māori Subject Headings Success! In Proceedings of the 5th International Indigenous Librarians Forum: Brisbane, Australia June 4-7, 2007. Brisbane, Australia. Retrieved from http:// natlib.govt.nz/records/30036574

New Zealand Ministry for Culture and Heritage Te Manatū Taonga. (2013). The Māori language. In Te Ara - the Encyclopedia of New Zealand. Wellington, N.Z.: New Zealand Ministry for Culture and Heritage Te Manatu Taonga. Retrieved from http://www.teara.govt.nz/en/te-reomaori-the-maori-language/page-1

Nicolas, Y. (2003). A French perspective: making the National Library of New Zealand responsive to Maori. New Zealand Libraries, 49(9), 309-313. 
Olson, H. A., \& Schlegl, R. (2001). Standardization, objectivity, and user focus: a meta-analysis of subject access critiques. Cataloging \& Classification Quarterly, 32(2), 61-80. http://doi.org/10.1300/J104v32n02_06

Onwuegbuzie, A. J., \& Teddlie, C. (2003). A framework for analyzing data in mixed methods research. In A. Tashakkori \& C. Teddlie (Eds.), Handbook of mixed methods in social \& behavioral research (pp. 351-184). Thousand Oaks, Calif: SAGE Publications.

Paewai, R., \& Reweti, A. (2014). Ngā Ūpoko Tukutuku: Māori Subject Headings Thesaurus. In Collaboration in the Asia Pacific Century. Jeju, South Korea: OCLC. Retrieved from http://www.oclc.org/content/dam/oclc/councils/asiapac/meetings/2014annual/tuesdaypd fs/paewai-reweti.pdf

Paranihi, J. (2011a). Ka eke panuku, ka eke Tangaroa: Steering into the future. Presented at the Te Rōpū Whakahau Hui-ā-Tau 2011, Te Oreore Marae, Wairarapa, N.Z.

Paranihi, J. (2011b). Tū te ihi, tū te wehi, tū te wana: Māori Subject Headings and empowerment through access. Presented at the LIANZA Conference, 29 Oct - 2 Nov 2011, Wellington, N.Z. Retrieved from http://www.lianza.org.nz/tu-te-ihi-tu-wehi-wana-nga-upoko-tukutukuand-empowerment-through-access

Paranihi, J. (2013). Ngā Ūpoko Tukuktuku/Māori Subject Headings and Iwi-Hapu Names Projects. In L. Roy \& A. Frydman (Eds.), Library Services to Indigenous Populations: Case Studies | IFLA. Retrieved from http://www.ifla.org/publications/library-services-to-indigenouspopulations-case-studies

Parekowhai, C., \& Black, R. (1990). Bus stop, wet day, she’s there, I say. Archifacts, 29-35.

Pipi, K., Cram, F., Hawke, R., Hawke, S., Huriwai, T. M., Mataki, T., ... Tuuta, C. (2004). A research ethic for studying Māori and iwi provider success. Social Policy Journal of New Zealand, (23). Retrieved from http://www.msd.govt.nz/about-msd-and-our-work/publicationsresources/journals-and-magazines/social-policy-journal/spj23/23-a-research-ethic-forstudying-mori-and-iwi-provider-success-p141-153.html

Punch, K. (2014). Introduction to social research: quantitative \& qualitative approaches (3rd ed). Los Angeles, California: SAGE.

Rankin, E., \& Steer, R. (2013). Te puāwaitanga o te tangata - The blossoming of people - Aranui Library, enhancing the lives of the community. | Lianza Conference Proceedings 2013. Retrieved April 7, 2014, from http://www.lianza.org.nz/resources/conference- 
proceedings $/ 2013 /$ te-pu $\%$ C4\%81waitanga-o-te-tangata-blossoming-people- $\%$ E2\%80\%93aranui-library

Reitz, J. M. (2014). Subject headings - ODLIS Online Dictionary for Library and Information Science. ODLIS Online Dictionary for Library and Information Science. Santa Barbara, CA: ABCCLIO. Retrieved from http://www.abc-clio.com/ODLIS/odlis_s.aspx\#subjectheading

Ritchie, A. J. R. (2013). Pākēhā librarianship at the interface: Being an ally in Māori student success through teaching and learning information literacies. Retrieved from http://researcharchive.vuw.ac.nz/handle/10063/2862

Simpson, S., Library \& Information Association of New Zealand Aotearoa, National Library of New Zealand, \& Te Rōpū Whakahau. (2005). Te ara tika: Ngā Ingoa Kaupapa Māori: pürongo tuatoru = Guiding words: Māori Subject Headings Project: phase 3 research report. [Wellington, N.Z: Te Rōpū Whakahau].

Smith, L. T. (2005). On tricky ground: Researching the native in the age of uncertainty. In N. K. Denzin \& Y. S. Lincoln (Eds.), The SAGE handbook of qualitative research (3rd ed, pp. 85-108). Thousand Oaks: Sage Publications.

Statistics New Zealand. (2013). Steady growth in Māori population continues - Statistics New Zealand. Retrieved August 10, 2014, from http://www.stats.govt.nz/Census/2013census/profile-and-summary-reports/qstats-about-maori-english-mr.aspx

Stevens, A. (2004). Are you Te Kaitiaki Pukapuka?: Bilingual staffing and ownership of Māori information. New Zealand Libraries, 49(11), 371-376.

Szekely, C., \& New Zealand Library and Information Association. (1997). Te Ara Tika II = Guiding voices: bui transcripts and summaries. Wellington, N.Z: NZLIA.

Ta'ala, T. (2008). Te wero i te Ūpoko Tukutuku - The challenge of Māori Subject Headings. Presented at the LIANZA Conference. Retrieved from http://www.lianza.org.nz/te-wero-ite- $\%$ C $5 \%$ ABpoko-tukutuku- $\% \mathrm{E} 2 \% 80 \% 093$-challenge-m $\% \mathrm{C} 4 \% 81$ ori-subject-headings- 0

Taitoko, G. (2003). Māori subject headings: A N.Z. "monster" currently with 3 heads. In D. Ongley (Ed.), International Indigenous Librarians' Forum III: proceedings 2003 (pp. 112-117). Santa Fe, New Mexico, USA: American Indian Library Association.

Te Aka Online Māori Dictionary. (n.d.). tikanga - Māori Dictionary. Retrieved April 19, 2015, from http:/ / www.maoridictionary.co.nz/search?idiom =\&phrase=\&proverb=\&loan=\&keywords $=$ tikanga 
Te Rōpū Whakahau. (2015b). Ngā Ūpoko Tukutuku | Māori Subject Headings. Retrieved August 10, 2014, from http://www.trw.org.nz/current-projects/nga-upoko-tukutuku-maori-subjectheadings/

Te Rōpū Whakahau. (2015a). Te Rōpū Whakahau - Nau mai, haere mai, whakatau mai! Retrieved May 6, 2015, from http://www.trw.org.nz/

Te Whakakaokao (Ngā Ūpoko Tukutuku Reo Māori Working Group). (2013). Māori Subject Headings Nga Ūpoko Tukutuku. Retrieved August 10, 2014, from http://mshupoko.natlib.govt.nz/mshupoko/index.htm

Tikao, A., \& Frean, N. (2013). Titiro ki muri: Resurfacing Māori collections through improved arrangement \& description: A case study. Archifacts, 23-31.

Tobin, K. (n.d.). Report back: Mātauranga Māori Within New Zealand Libraries Workshop | Lianza. Retrieved from http://www.lianza.org.nz/community/ikaroa/post/report-back$\mathrm{m} \% \mathrm{C} 4 \% 81$ tauranga-m\%C4\%81 ori-within-new-zealand-libraries-workshop

Todd, C. (1998). Maori Subject Headings: A work in progress, 24(3/4), 83-92.

Waitangi Tribunal. (2011). Ko Aotearoa Tènei: A report into claims concerning New Zealand law and policy affecting Māori culture and identity. Te taumata tuarua: volume 2. Wellington, N.Z.: Waitangi Tribunal. Retrieved from https://forms.justice.govt.nz/search/WT/reports/reportSummary.html?reportId=wt_DOC _68356606

Wara, R. T. (2001). Case studies of successful implementations of bicultural policies and practices in Aotearoa New Zealand public libraries: Submitted to the School of Communications and Information Management Victoria University of Wellington in partial fulfilment of the requirements for the degree of Master of Library and Information Studies. Victoria University of Wellington, Wellington, N.Z.

Warren, G. T. (2006). Librarian myths and legends for Maori: He kupu, he whakaaro, he waiata. Victoria University of Wellington, Wellington, N.Z. Retrieved from http://researcharchive.vuw.ac.nz/handle/10063/3115

Watson, L. (2004). Recognition of indigenous terms of reference. Presented at the A Contribution to Change: Cooperation out of Conflict Conference: Celebrating Difference, Embracing Equality, Hobart, Australia. Retrieved from http://www.theblackcard.com.au/lilla-watson/ Webster, K., \& Doyle, A. (2008). Don't class me in Antiquities. In K. R. Roberto (Ed.), Radical cataloging: essays at the front. Jefferson, N.C: McFarland \& Co. 
Wehipeihana, N., Davidson, E. J., McKegg, K., \& Shanker, V. (2010). What does it take to do evaluation in communities and cultural contexts other than our own? Journal of MultiDisciplinary Evaluation, 6(13), 182-192.

Wehipeihana, N., Pipi, K., Kennedy, V., \& Paipa, K. (2013). Hinewhārauriki: Tapestries of life for four Māori women in evaluation. In D. M. Mertens, F. Cram, \& B. Chilisa (Eds.), Indigenous pathways into social research: voices of a new generation (pp. 277-298). Walnut Creek, Calif: Left Coast Press.

Yin, R. K. (2014). Case study research: design and methods (Fifth edition). Los Angeles: SAGE. 


\section{Appendix 1. Research question and sub-questions}

\section{How are research libraries in Aotearoa New Zealand applying Ngā Ūpoko Tukutuku, the Māori Subject Headings, and offering them to users?}

1. Who is adding the MSH terms, how, and with what support/guidance? (Cataloguing/indexing/arrangement and description)

a. Who adds MSH terms? Only metadata librarians? Māori specialist librarians? Suppliers?

b. What level of knowledge of te reo Māori do these staff have?

c. In what cases are subject headings added?

- Only if the content of an item is more than $20 \%$ on a certain subject? - Can staff tag an item (using MSH terms) to get around this restriction?

- Retrospectively, or only for new items?

d. Where do metadata librarians look for help within their libraries? How closely do Māori specialist librarians work with metadata librarians to enrich catalogue entries, discuss queries, plan strategies?

e. Where do metadata librarians look for help outside of their organisations? Have libraries sent enquiries/suggestions/wero to the MSH team?

f. What further help do libraries want?

g. Do staff access the MSH from the home website? If so, how easy is it to use? What do staff like about the interface? What further improvements could they suggest?

h. After libraries add subject headings, do staff send these to the National Union Catalogue?

i. If subject headings are added by suppliers or an external cataloguing service, how is quality control monitored?

j. Are the terms chosen tailored to user needs - for example, by identifying course content in educational libraries?

2. How are librarians using the MSH terms and thesaurus when searching with users? Reference \&o research services)

a. Are frontline staff (enquiries desk, reference staff, research librarians ...) aware of the MSH?

b. How do staff use the MSH while searching?

c. Do staff who don't feel fluent in te reo use the MSH as a reference tool or cultural interface, to help them understand or frame users' enquiries?

3. How are libraries displaying the MSH to users, and supporting/guiding their use? (Independent searching)

a. Visible on item records in online catalogue.

b. Explained in research guides, online or on paper. 
c. Taught in information literacy sessions.

d. Displayed around the library, eg. on shelves.

e. In other ways... 


\section{Appendix 2. The "long list" of research questions}

My summary of the research questions proposed by -

- Te Whakakaokao/ the Mäori Subject Headings Working Group and the MSH Governance Group on 22.8.14, and in discussion with members of Te Whakakaokao during August

- Wellington Māori librarians at the Te Rōpü Whakahau regional hui for Te Ūpoko o te Ika on 19.9.14

\section{Big question: How are libraries offering Ngā Ūpoko Tukutuku, the Māori Subject Headings, to their users?}

\section{Why research this?}

- Provide one avenue for libraries to share their good ideas with each other and finding out what could work better, to facilitate the use of the MSH.

- Document library staff experiences of the benefits of the MSH for staff and users, to motivate more libraries to use the MSH.

- Document what areas require further investigation by future researchers.

\section{Many questions within this!}

\section{Who is applying the MSH and offering them to users?}

[n this project, an environmental scan of publicly available information gathered some examples, although an exhaustive representation giving valid proportions of all possible repositories will have to wait for a future researcher.]

What kinds of information organisations and memory institutions are applying the MSH?

- Wānanga, kura kaupapa, kohanga reo, puna reo?

- Universities, schools? Other educational libraries, eg. the Nola Miller Library (for the NZ School of Dance and Toi Whakaari, within Te Whaea)?

- Public libraries?

- The National Library?

- Government departments, Crown Research Institutes and Crown entities, eg. Te Puni Kōkiri, Te Taura Whiri/Māori Language Commission, Scion (New Zealand Forest Research Institute)?

- Judicial and other independent bodies, eg. the Waitangi Tribunal or the Māori Land Court? 
- Iwi repositories/whare taonga?

- Archives? Records managers?

- Museums - large publicly-funded or local volunteer-run museums?

- $\quad$ [And also: Publishers?]

What kinds of repositories could be using the MSH, but are not yet?

- Who is aware of them?

- Who would like to use them?

- What would make this possible?

\section{How are libraries applying the MSH and offering them to users?}

[n this project, interviews synthesized perspectives from several environments/settings within various types of research libraries in the Te Ūpoko o te Ika a Māui/greater Wellington region - a wānanga library, a government department library, large public or national libraries with significant research/manuscript collections, and university libraries. A broader view of how other information organisations and memory institutions are engaging with the MSH will have to wait for a future researcher.]

\section{Who is adding the MSH terms, how, and with what support/guidance?}

\section{(Cataloguing/indexing/arrangement and description)}

In libraries which apply any subject headings themselves -

- Who adds MSH terms? Only metadata librarians? Māori specialist librarians? Suppliers?

- What level of knowledge of te reo Māori do these staff have?

- In what cases are subject headings added?

- Only if the content of an item is more than $20 \%$ on a certain subject? - Can staff tag an item (using MSH terms) to get around this restriction [this helps with keyword searches, though not subject searches]?

- Retrospectively, or only for new items?

- Where do metadata librarians look/who do they ask for help?

- How closely do Māori specialist librarians work with metadata librarians to enrich catalogue entries, discuss queries, plan strategies?

- Have libraries sent enquiries/suggestions/wero to the MSH team? 
- What further help do libraries want?

- Do staff access the MSH from the home website? If so, how easy is it to use? What do staff like about the interface? What further improvements could they suggest?

- After libraries add subject headings, do staff send these to the National Union Catalogue?

- Are the terms chosen tailored to user needs - for example, by identifying course content in educational libraries?

If subject headings are added by suppliers or an external cataloguing service, how is quality control monitored?

How are librarians using the MSH terms and thesaurus when searching with users?

(Reference \& research services)

Are frontline staff (enquiries desk, reference staff, research librarians . . .) aware of the MSH?

How do staff use the MSH while searching?

Do staff who don't feel fluent in te reo use the MSH as a reference tool or cultural interface, to help them understand or frame users' enquiries?

\section{How are libraries presenting the MSH to users, and supporting/guiding their use?}

(Independent searching)

How are the MSH presented to users?

- Visible on item records in online catalogue. [This can be assessed using the libraries' public websites.]

- Explained in research guides, online or on paper.

- Taught in information literacy sessions.

- Displayed around the library, eg. on shelves.

- In other ways ...

\section{What do libraries know about how library users are interacting with the MSH?}

In preparation for this project, a small exploratory analysis was performed on log data provided by one library, as described in the "Research problem" section of this report. Broader and more indepth analysis, including discussion with library users, will have to wait for a future researcher.]

What information do repositories have about users' independent or assisted interaction with the MSH? (And what can they share with researchers?) 
Kōrero/stories/queries, eg.

- Working notes, enquiry statistics, etc.

- Email enquiries to library's enquiries portal or to individual specialist librarians.

- Librarians' own memories/observations.

- Conversations in online forums, eg. discussion lists.

Log data, eg.

- Search strings entered by library users.

- Clickthroughs for subject heading links in the online catalogue.

What could we observe? (eg. by experimentally tracking sample searches)

\section{In summary:}

\section{What do we know about what works for librarians and library users?}

- What factors and processes are enabling success?

- In what way is it working? - What good things do we see happening because the MSH are available?

\section{What could work better?}

- What are the barriers?

- What would make it easier for library users to benefit from the MSH? 


\section{Appendix 3. Participant information sheet and consent form}

The participant information sheet and participant consent form on the following pages relate to

Human Ethics Committee approval for this study, as noted in the "Ethical considerations" section of this report. 


\section{Participant Information Sheet}

Research Project Title: How are New Zealand research libraries applying Ngā Ūpoko Tukutuku/the Māori Subject Headings and offering them to users?

\section{Researcher: Melissa Bryant, School of Information Management, Victoria University of Wellington}

As part of the completion of my Master of Information Studies, this study is designed to explore how research libraries are applying Ngā Ūpoko Tukutuku/the Māori Subject Headings (MSH) and offering them to their users.

I hope to investigate -

- Who is adding the MSH terms, how, and with what support/guidance?

- How are librarians using the MSH terms and thesaurus when searching with users?

- How are libraries displaying the MSH to users, and supporting/guiding their use?

The aims of the study are to -

- Provide one avenue for libraries share their good ideas regarding with each other, to facilitate the use of the MSH.

- Find out what could work better.

- Document the benefits to staff and users, to encourage more libraries to use the MSH.

- Document what areas remain for further investigation by future researchers.

Victoria University requires, and has granted, approval from the School's Human Ethics Committee.

I am inviting those who have experience of working with the MSH within research libraries to participate in this research. This experience may include reference/research, Māori specialist, and/or cataloguing/indexing/arrangement and description work. Participants will be asked to take part in a onehour interview, either individually or in focus groups according to their preferences. Permission will be asked to record the interview, and a summary of the interview will be sent to participants for checking.

Participation is voluntary. Participants and their employers will not be identified personally in any written report produced as a result of this research, including possible publication in academic conferences and journals. All material collected will be kept confidential, and will be viewed only by myself and my supervisor Dr Sydney Shep, Associate Professor/Reader in Book History, Wai-te-Ata Press. The research report will be submitted for marking to the School of Information Management, and subsequently deposited in the University Library. Should any participant wish to withdraw from the project, they may do so until 6 April 2015, or before the session in the case of participants in focus groups, and the data collected up to that point will be destroyed. All data collected from participants will be destroyed within 2 years after the completion of the project. 
If you have any questions or would like to receive further information about the project, please contact me at Melissa.Bryant@vuw.ac.nz or telephone 021488 8817, or you may contact my supervisor Dr Sydney Shep, Associate Professor/Reader in Book History, Wai-te-Ata Press at sydney.shep@vuw.ac.nz or telephone 044635784 .

Melissa Bryant 


\section{Participant Consent Form}

Research Project Title: How are New Zealand research libraries applying Ngā Ūpoko Tukutuku/the Māori Subject Headings and offering them to users?

\section{Researcher: Melissa Bryant, School of Information Management, Victoria University of Wellington}

I have been given and have understood an explanation of this research project. I have had an opportunity to ask questions and have them answered to my satisfaction.

I understand that I may withdraw myself (or any information I have provided) from this project, without having to give reasons, by e-mailing Melissa.Bryant@vuw.ac.nz by 6 April 2015. If I am participating in a focus group, I may withdraw my participation before the session (after the session, it would be too difficult for the researcher to identify and erase one participant's contributions from a recording of a group discussion).

I understand that any information I provide will be kept confidential to the researcher and their supervisor, the published results will not use my name, and that no opinions will be attributed to me in any way that will identify me or my employer.

I understand that the data I provide will not be used for any other purpose or released to others.

I understand that, if this interview is audio recorded, the recording and written summaries of the interviews will be erased within 2 years after the conclusion of the project. Furthermore, I will have an opportunity to check the summary of the interview.

Please indicate (by ticking the boxes below) which of the following apply:

I would like to receive a summary of the results of this research when it is completed.

I agree to this interview being audio recorded.

Signed:

Name of participant:

Date: 


\section{Appendix 4. Interview schedule}

\section{Interview schedule}

(The interview process varied depending on the local kawa/etiquette and preferences of each library and participant or group of participants involved.)

\section{Greetings and whakawhanaungatanga}

Explanation of main research question: How are research libraries in Aotearoa New Zealand applying Ngā Ūpoko Tukutuku/the Māori Subject Headings and offering them to users?

Explanation of research objectives -

- Provide one avenue for libraries to share their good ideas with each other and finding out what could work better, to facilitate the use of the MSH.

- Document library staff experiences of the benefits of the MSH for staff and users, to motivate more libraries to use the MSH.

- Document what areas still require further investigation by future researchers.

I will take notes, record, keep notes and recording plus notes on the recording for two years in password-protected private computer, then destroy. Is everyone comfortable with that?

I will keep participants and libraries confidential.

Interview will be around an hour. Questions are not yes/no - I'd like to hear participants' thoughts, generate discussion and stories. If we've talked informally about this topic before, please DO feel free to repeat yourself as this is the conversation which will be "on the record"!

\section{Questions for discussion}

Who is adding the MSH terms, how, and with what support/guidance?

\section{(Cataloguing/indexing/arrangement and description)}

For subject headings which are applied within your library -

- Who adds MSH terms? Only metadata librarians? Māori specialist librarians? Suppliers?

- What level of knowledge of te reo Māori do these staff have?

- In what cases are subject headings added?

- Only if the content of an item is more than $20 \%$ on a certain subject? - Can staff tag an item (using MSH terms) to get around this restriction?

- Retrospectively, or only for new items? 
- Where do metadata librarians look/who do they ask for help?

- How closely do Māori specialist librarians work with metadata librarians to enrich catalogue entries, discuss queries, plan strategies?

- Have libraries sent enquiries/suggestions/wero to the MSH team?

- What further help do libraries want?

- Do staff access the MSH from the home website? If so, how easy is it to use? What do staff like about the interface? What further improvements could they suggest?

- After libraries add subject headings, do staff send these to the National Union Catalogue?

- Are the terms chosen tailored to user needs - for example, by identifying course content in educational libraries?

If subject headings are added by suppliers or an external cataloguing service, how is quality control monitored?

\section{How are librarians using the MSH terms and thesaurus when searching with users?}

(Reference \& research services)

Are frontline staff (enquiries desk, reference staff, research librarians . . .) aware of the MSH?

How do staff use the MSH while searching?

Do staff who don't feel fluent in te reo use the MSH as a reference tool or cultural interface, to help them understand or frame users' enquiries?

\section{How are libraries displaying the MSH to users, and supporting/guiding their use?}

\section{(Independent searching)}

How are the MSH displayed to users?

- Visible on item records in online catalogue.

- Explained in research guides, online or on paper.

- Taught in information literacy sessions.

- Displayed around the library, eg. on shelves.

- In other ways.

\section{What else is important to share?}

\section{Closing thoughts}

I will summarise/selectively transcribe the interview, to produce a written record of timecodes along with topics or questions discussed, key information provided and pertinent quotations. 
I will send this to participants for checking by 6 April, and hope they will be able to reply by 20 April. Participants in individual interviews can withdraw or amend their contributions until 6 April, although it is not possible to identify and destroy only one participant's part of the audio recording of a focus group discussion.

I will return the knowledge gathered to all partipants in early June, in their chosen format. Closing thanks.

Perhaps some kai for whakanoatanga and whakawhanaungatanga? 
Name:

Course number:

Word count:
Melissa Bryant

INFO 580

11, 980

(not including abstract, reference list or appendices) 